\title{
The Urban Food Hubs Solution: Building Capacity in Urban Communities
}

Sabine O'Hara

\begin{abstract}
Access to affordable fresh food is an ongoing challenge for underserved urban neighborhoods across the United States. Several are designated food deserts with no access to a full-service grocery store within a one-mile radius. The Urban Food Hubs of the College of Agriculture, Urban Sustainability, and Environmental Sciences (CAUSES) of the University of the District of Columbia (UDC) exemplify the University's commitment to building capacity in the food desert neighborhoods of Washington D.C. The four components of the Urban Food Hubs are food production, food preparation, food distribution, and waste and water recovery (http://www.udc.edu/category/causes). They are designed to not only provide access to fresh food, but also to create jobs, improve public health, mitigate water management problems, and create urban resiliency. The contributions in economic, social/cultural, and physical/environmental impacts, and the five pillars of economic development that track the broader impacts of urban capacity building are described here. The Urban Food Hubs demonstrate the investment metropolitan universities could make to ensure the long-term economic, social, and environmental health of each community. The model is scalable and replicable in other metropolitan areas, including those that experience high pressure on land-use and those experiencing decline.
\end{abstract}

\section{Keywords \\ Capacity building, Urban food systems, Urban agriculture, Urban sustainability, Resilience, Community-based economic development}

\section{Introduction}

Universities have long played an important role in building the economic capacity of the communities they serve. Universities provide employment, offer education and training, and conduct research to meet the economic, social, and environmental development needs of the future (Abel \& Dietz, 2012; Porter, 2007; Siegfried, Sanderson, \& McHenry 2007). Metropolitan Universities, those that serve urban and peri-urban communities, play a particularly important capacity building role given the diversity and disparity of urban communities. Most cities are bifurcated; some neighborhoods have high household incomes, high education levels, low unemployment, and abundant access to amenities and services; others have low household incomes, high unemployment, and limited access to everything from medical services to restaurants and fresh food (Berube \& Homes, 2015; Baum-Snow \& Pavan, 2011).

As the only public university in Washington D.C., and the only exclusively urban land-grant university in the United States, the University of the District of Columbia (UDC) and its College of Agriculture, Urban Sustainability, and Environmental Sciences (CAUSES) developed a focus on urban agriculture and urban sustainability to address the needs of its diverse urban 
constituencies. This unique focus finds expression in the UDC Urban Food Hubs initiative. The Urban Food Hubs seek to improve quality of life and economic opportunity through a comprehensive urban food system that meets the needs of both the underserved neighborhoods lacking access to fresh food and the high-end markets associated with the fast growing local foods movement (O’Hara, 2015).

Unlike some of the shrinking metropolitan areas in the United States, which have developed a focus on urban agriculture to find new uses for abandoned neighborhoods, the Washington D.C. metropolitan area is growing. It is therefore an ideal location to test the viability of an urban food system that can compete in an environment of strong land-use pressures. The four components of the UDC Urban Food Hubs - food production, food preparation, food distribution, and waste and water recovery - are designed to establish: (a) high-efficiency urban food production sites; (b) commercial kitchens to improve nutritional health and add value by turning produce into food products; and (c) green infrastructure that remediates urban soils and improves water use efficiency. Each Urban Food Hub is a business incubator to create jobs and address health disparities. As will be discussed in a later section of this article, this makes the UDC Urban Food Hubs more comprehensive than the food hubs definition of the United States Department of Agriculture (Barham et al, 2012).

There are direct and indirect benefits of the UDC Urban Food Hubs and investing in them is a way to operationalize the capacity building mission of metropolitan universities. Beyond implications for Washington D.C., the Urban Food Hubs can serve as a model for economic development that focuses on economic, social, and environmental benefits. By making the social and environmental impacts the focus of economic development, the measures of economic development success are redefined to ensure more sustainable outcomes. Table 1 summarizes the four components, locations, and programs of the UDC Urban Food Hubs in Washington D.C.

Table 1

\section{UDC CAUSES Urban Food Hub}

\begin{tabular}{|c|c|c|c|c|c|}
\hline \multirow[t]{2}{*}{$\begin{array}{l}\text { UDC Urban } \\
\text { Food Hubs }\end{array}$} & \multicolumn{4}{|c|}{$\begin{array}{l}\text { Food Components (and Related Education) } \\
\text { (Sustainable Economic, Social, Environmental Health) }\end{array}$} & \multirow{2}{*}{$\begin{array}{l}\text { Student, Faculty and } \\
\text { Community } \\
\text { Engagement }\end{array}$} \\
\hline & Production & Preparation & Distribution & Waste \& Water & \\
\hline $\begin{array}{l}\text { Van Ness } \\
\text { campus } \\
\text { Ward } 3\end{array}$ & $\begin{array}{l}\text { Green roof, } \\
\text { hydroponics, } \\
\text { aquaponics }\end{array}$ & $\begin{array}{l}\text { Commercial } \\
\text { kitchen; teaching } \\
\text { kitchen }\end{array}$ & $\begin{array}{l}\text { Farmers market; } \\
\text { CSA; restaurant } \\
\text { contracts }\end{array}$ & $\begin{array}{l}\text { Rainwater harvest; } \\
\text { water runoff reuse }\end{array}$ & $\begin{array}{l}\text { Experiential learning, } \\
\text { research, land-grant } \\
\text { workshops, demonstra- } \\
\text { tions, certificates }\end{array}$ \\
\hline $\begin{array}{l}\text { Betrie Backus } \\
\text { campus } \\
\text { Ward } 5\end{array}$ & $\begin{array}{l}\text { Hydroponics, } \\
\text { aquaponics, } \\
\text { native plant nursery }\end{array}$ & $\begin{array}{l}\text { Commercial and } \\
\text { teaching kitchen } \\
\text { under construction }\end{array}$ & TBD & $\begin{array}{l}\text { Rain garden design, } \\
\text { installation, and } \\
\text { maintenance }\end{array}$ & TBD \\
\hline $\begin{array}{l}\text { East Capitol } \\
\text { Urban Farm } \\
\text { Ward } 7\end{array}$ & $\begin{array}{l}\text { Aquaponics, raised bed } \\
\text { gardens }\end{array}$ & Food truck & Farmers market & $\begin{array}{l}\text { Rain garden; rice } \\
\text { field }\end{array}$ & $\begin{array}{l}\text { Land-grant workshops, } \\
\text { demonstrations, and } \\
\text { certificates; research }\end{array}$ \\
\hline $\begin{array}{l}\text { PR Harris } \\
\text { campus } \\
\text { Ward } 8\end{array}$ & $\begin{array}{l}\text { Hydroponics, } \\
\text { aquaponics, raised bed } \\
\text { gardens }\end{array}$ & Food truck & TBD & TBD & TBD \\
\hline
\end{tabular}

\section{Why Urban Food Hubs?}


The University of the District of Columbia is a comprehensive, public, minority serving, landgrant university that was formed from three precursor institutions: Washington Technical Institute, Federal City College, and D.C. Teachers College. Of all the land-grant universities in the United States, UDC is the only one that serves an exclusively urban territory (National Research Council, 1995). In 2011, the University formed its College of Agriculture, Urban Sustainability, and Environmental Sciences (CAUSES) to reaffirm its urban land-grant mission, and to bring the university's land-grant programs into closer alignment with its academic programs.

CAUSES set out to embrace its unique mission and develop a focus on urban agriculture, urban sustainability, and resilience. The college offers academic programs in architecture, health education, nursing, nutrition and dietetics, urban sustainability, urban agriculture, and water resources management. The applied research and community outreach functions - typically offered through separate Agricultural Experiment Station (AES) and Cooperative Extension Service (CES) programs - are combined and offered through five land-grant centers that are aligned with the college's urban agriculture and urban sustainability focus. Centers include the Center for Urban Agriculture and Gardening Education; the Center for Sustainable Development and Resilience; the Center for Nutrition, Diet, and Health; the Center for Architectural Innovation and Building Science; and the Center for 4-H and Youth Development.

The mission statement of CAUSES affirms the college's commitment to "... offer researchbased academic and community outreach programs that improve the quality of life and economic opportunity of people and communities in the District of Columbia, the nation, and the world." In 2013, CAUSES adopted its tagline Healthy Cities - Healthy People to affirm its capacity building mission as inextricably linked to improving the environmental/physical condition and the social/cultural condition of the urban community it serves. The commitment to improve quality of life and economic opportunity must therefore be understood as a commitment to improve not only economic outcomes, but also the social/cultural and physical/environmental context within which every economic activity takes place (O’Hara, 1995, 1997).

To give practical expression to this commitment, CAUSES developed an Urban Food Hub model. Like most cities, Washington D.C. is bifurcated. Administratively, the city is organized into eight wards. Ward 8 has the lowest median household income level of \$32,000 per year, an unemployment rate of close to $20 \%$, and $90 \%$ of its residents are African or African-American. Ward 3 has a median household income of $\$ 110,000$ per year, an unemployment rate of less than $4 \%$, and $5 \%$ of its residents are African-American (United States Bureau of the Census, 2014).

Similar disparities are evident in food security and health parameters. The United States Department of Agriculture defines food security as “... access by all people at all times to enough nutritious food for an active, healthy life" (United States Department of Agriculture, 2014). Low food security implies that high quality food is unavailable at least some of the time for some people. Wards 5, 7, and 8, the three D.C. wards with the lowest income levels, are home to $34 \%$ of the population, yet less than $10 \%$ of the city's grocery stores are located there (see Figure 1); and less than 10\% of the 520 self-identified food retailers in Washington D.C. offer an adequate variety of fresh produce to support a healthy diet. 


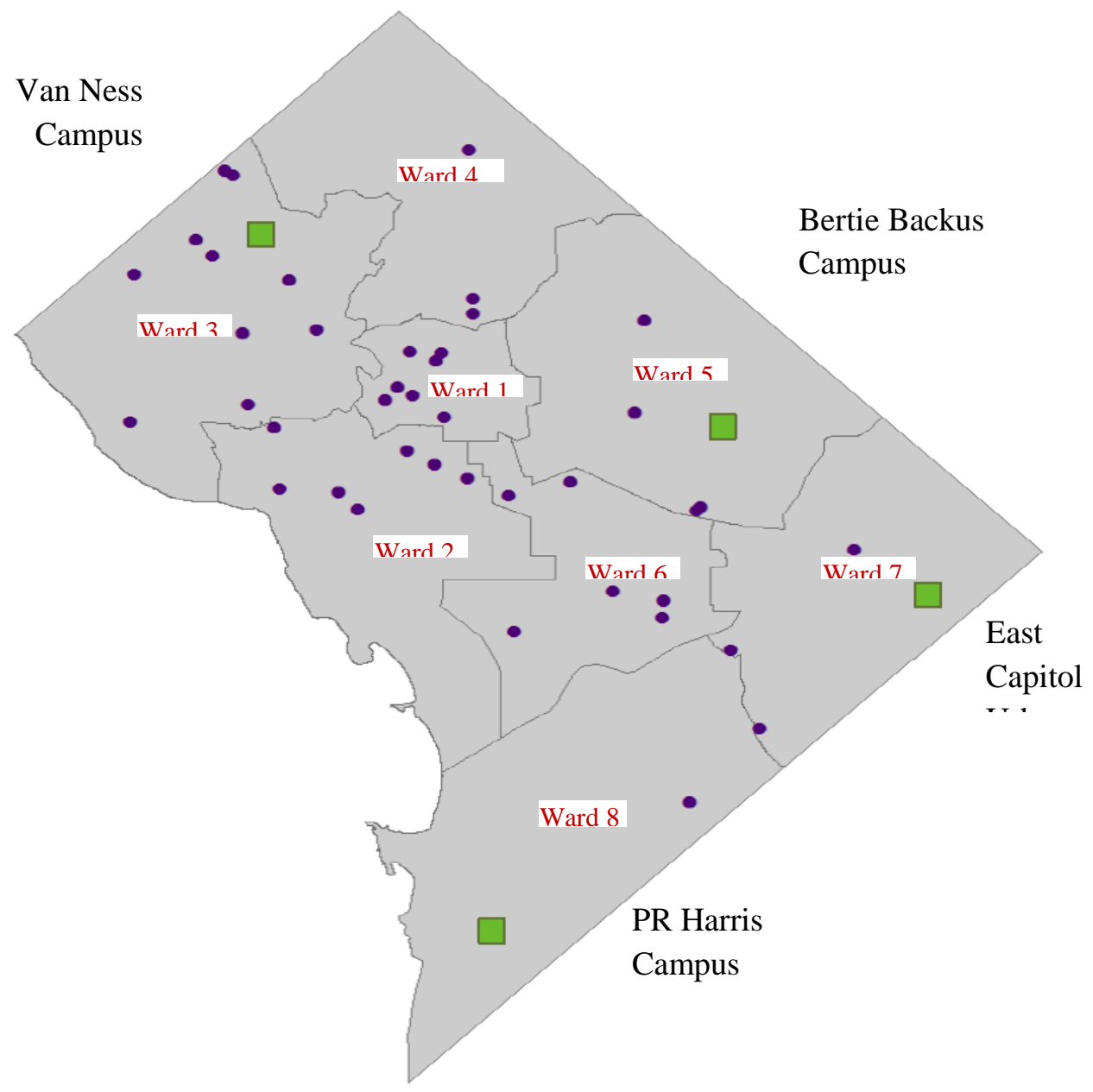

Figure 1. Full-service Grocery Stores and Urban Food Hubs in Washington D.C. The result is food insecurity for a significant number of D.C. households: $13 \%$ report being food insecure; $19 \%$ experience food hardship; and $37 \%$ of households with children were unable to get enough food (D.C. Department of Health, 2013). Among the damaging effects of food insecurity on children are impaired cognitive development, reduced school readiness, lower educational attainments, and slower physical, mental, and social development (Cook et al., 2006; Nord, Coleman-Jensen, Andrews, \& Carlson, 2010).

Another concern stems from the declining nutrient content of some of our food (USDA, 2014). One contributing factor is the increased time between harvest and consumption. To accommodate the time spent in transport, produce is harvested before it ripens. Populations in urban areas on the east coast of the United States are especially vulnerable since California is the top producer of fruits and vegetables. This calls for an increase in the production of nutrient 
dense produce closer to where the majority of consumers live, namely in metropolitan areas on the east coast of the United States. Growing perishable food closer to where consumers live also reduces the energy use associated with food transportation (Canning, Charles, Huang, Polenske, \& Waters, 2010; Weber \& Matthews, 2008).

Historically, cities are not locations where much food has been grown (Gorgolewski, Komisar, \& Nasr, 2011; United Nations Development Program, 1996). Firebird Farm, the UDC research farm located just beyond city limits in Beltsville, Maryland, seeks to change that. It is dedicated to urban agriculture and its research focuses on how to produce food sustainably in urban neighborhoods where space is a premium. The UDC Urban Food Hubs take the UDC farm into the city. The focus extends beyond farming to a comprehensive food system that supports skills development and job creation through food production, food preparation, new food distribution methods, and waste and water recovery. Similar to the Cooperative Extension offices that have shaped the capacity building mission of land-grant universities in rural counties across the United States (USDA 2015; USDA NIFA 2014), the Urban Food Hubs seek to build capacity in urban neighborhoods by focusing on the entirety of the urban food systems from food, to health and wellness, and green infrastructure.

\section{What is an Urban Food Hub?}

According to the Agricultural Marketing Service (AMS) of the United States Department of Agriculture (Barham et al., 2012), a food hub is "a business or organization that actively manages the aggregation, distribution, and marketing of source-identified food products primarily from local and regional producers to strengthen their ability to satisfy wholesale, retail, and institutional demand." This definition emphasizes the distribution component of the food system. To quote AMS, "Food hubs are an important subset of food value chains ... By offering a combination of aggregation, distribution, and marketing services at an affordable price, food hubs make it possible for many producers to gain entry into new larger-volume markets that boost their income and provide them with opportunities for scaling up production."

The UDC Urban Food Hubs further broaden the food hubs definition of the AMS. The reason for this comprehensive approach is that many urban dwellers have become distanced from their food source. Fresh unprocessed food is often unavailable, and there is a disconnect between consuming food and knowing where and how it is grown. Often the interest in the quality and origin of food is first triggered by an interest in cultural associations of food, or by a concern for food-related illnesses like obesity, diabetes, and hypertension (Brown \& Jameton, 2000; Webber \& Dollahite, 2008; Raj, Raja, \& Dukes, 2016)

Urban food production also intersects uniquely with urban sustainability considerations like storm-water management and waste reduction (Barthel \& Isendahl, 2013; O’Hara, 2015). Urban gardens, for example, increase permeable surfaces and green roofs absorb storm water run-off. Both reduce pressure on urban storm water systems that are at capacity in many of our cities (Agudelo-Vera, Mels, Kessman, \& Rijnaarts, 2011; James, Magee, Scerri, \& Steger, 2015; Lovell, 2010;). When food is produced in densely populated urban communities rather than in sparsely populated rural areas, issues like integrative pest management and mitigating heat islands must also come into focus (Li, Bou-Zeid, \& Oppenheimer, 2014; Wittmer et al., 2010). The four components of the UDC Food Hub address these complex connections: 
- food production through bio-intensive methods, hydroponics, and aquaponics;

- food preparation through kitchens that add value and offer nutrition education;

- food distribution through farmers markets, CSAs, restaurants, and niche markets; and

- closing the loop through composting, water harvesting, rain gardens, and other green infrastructure initiatives.

Each of these four components offers opportunities for business development, training, and improved resilience (see Figure 2). The Urban Food Hubs seek to form a decentralized network of local food centers that improve food security, nutritional health, job creation, and resilience especially in urban neighborhoods that have deficits on all counts.

The idea of strengthening local economies by replacing imports with local goods and services produced in decentralized local business networks is not new (Florida, 2005; Schuman, 2015). It has been called leak-plugging or re-localizing production (Schuman, 2002; New Economics Foundation, 2014). There are two principal strategies: to attract businesses to relocate in the community and to grow businesses from within. The UDC Urban Food Hubs promote the latter by focusing on local entrepreneurship.

Each food hub comprises a cluster of business opportunities for entrepreneurs who ideally come from the neighborhood where a Food Hub is located. Local entrepreneurs receive training and technical support to implement their business plans. These can range from a health-focused business that maximizes nutrient yield and offers health assessment and nutrition counseling; to growing micro-greens and herbs for high-end restaurants; to ethnic crop production for local niche restaurants and grocery stores; green roofs that serve as food production and event space; and native plant seedlings grown for urban parks and rain gardens (O'Hara, under review; Ackerman, Dalgren, \& Xu, 2012; Royte, 2015).

\section{The UDC CAUSES Urban Food Hubs Model}

\begin{tabular}{|c|c|c|c|}
\hline$\uparrow$ Food Production & $\rightarrow$ Food Preparation & $\rightarrow$ Distribution & Naste \& Water Recovery \\
\hline $\begin{array}{l}\text { Bio-intensive } \\
\text { Raised Beds } \\
\text { Aquaponics } \\
\text { Hydroponics } \\
\text { Green Roofs } \\
\text { Green Walls } \\
\text { Hoop Houses } \\
\text { Indoor Farms } \\
\text { Other }\end{array}$ & $\begin{array}{l}\text { Value Added } \\
\text { Processing } \\
\text { Preservation } \\
\text { Catering } \\
\text { Culinary } \\
\text { Nutrition Education } \\
\text { Other }\end{array}$ & $\begin{array}{l}\text { Farmers markets } \\
\text { Community Supported } \\
\text { Agriculture (CSAs) } \\
\text { Cooperatives } \\
\text { Food trucks } \\
\text { Restaurants } \\
\text { Corner stores } \\
\text { Other }\end{array}$ & $\begin{array}{l}\text { Composting } \\
\text { Bio digesters } \\
\text { Rainwater harvesting } \\
\text { Rain gardens } \\
\text { Water reuse } \\
\text { Other }\end{array}$ \\
\hline $\begin{array}{l}\text { University Owned } \\
\text { Cooperatively/Non- } \\
\text { Profit/Privately } \\
\text { Operated }\end{array}$ & $\begin{array}{l}\text { University Owned } \\
\text { Privately/Non-Profit } \\
\text { Owned } \\
\text { Privately Operated }\end{array}$ & $\begin{array}{l}\text { University Owned } \\
\text { Private, Non-Profit, } \\
\text { Public Ownership and } \\
\text { Operation }\end{array}$ & $\begin{array}{l}\text { University Owned } \\
\text { Private, Non-Profit, } \\
\text { Public Ownership and } \\
\text { Operation }\end{array}$ \\
\hline
\end{tabular}

Figure 2. The Urban Food Hubs as Comprehensive Food Systems Model. Each Urban Food Hub features the four components of food production, food preparation, food distribution, and waste 
and water recovery. Yet each specific design varies based on the urban density, site-specific characteristics, and business objectives of each location. What follows is a brief description of the four components of the UDC Urban Food Hubs that are currently in various stages of implementation in Wards 3, 5, 7, and 8 in Washington D.C.

\section{Food Production Through Intensive Urban Agriculture}

At the heart of each Urban Food Hub are highly efficient food production systems that utilize bio-intensive raised bed gardens, green roofs, hydroponic, and aquaponic to grow plants without soil in nutrient rich water. Regardless of the specific food production method a food hub utilizes, the aim is to maximize production on the limited land areas available in urban neighborhoods. The UDC Urban Food Hubs demonstrate several of these methods.

The University's Van Ness campus is located in Ward 3 at a high traffic intersection next to a metro station. Space is very limited in this high-density neighborhood. The food production component of the food hub is a 20,000-square-foot green roof that was installed on an existing roof structure (see Figure 3).
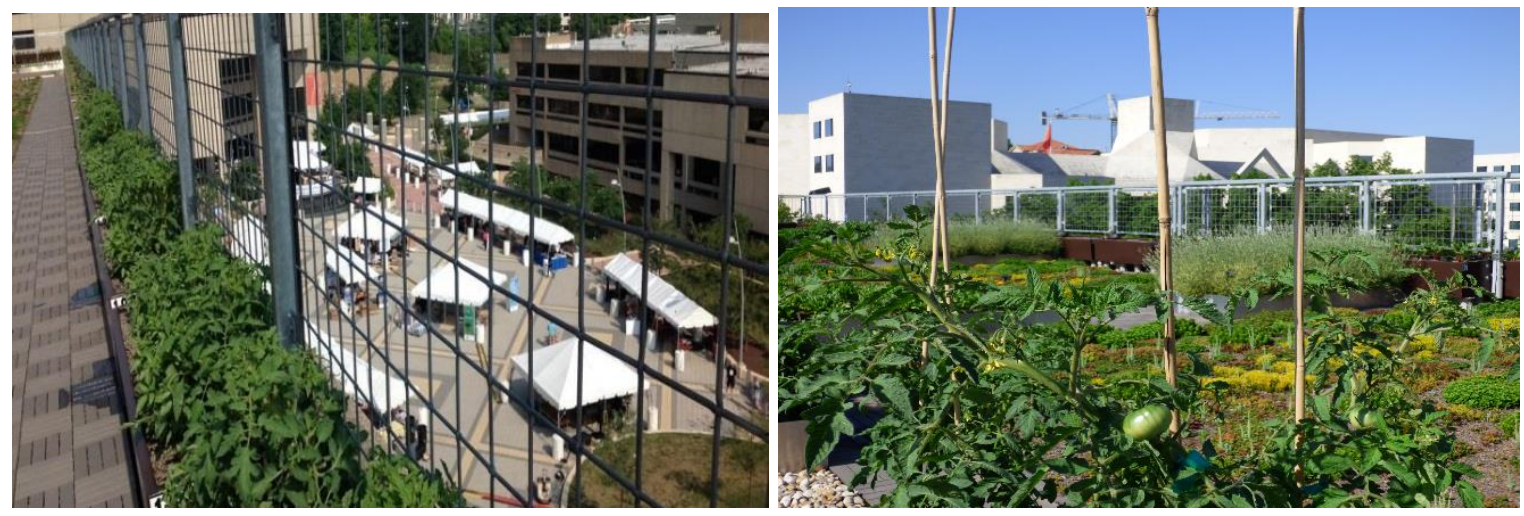

Figure 3. Food-Producing Green Roof of the UDC Van Ness Campus Urban Food Hub in Ward 3. Eighteen-inch deep planters placed around the perimeter of the roof support the production of a variety of food plants, from tomatoes to peppers, beans, okra, eggplant, and even berry bushes. The interior of the roof is limited to no more than four inches of soil depth, which can support the production of leaf lettuce, microgreens, and herbs. In its start-up phase the shallow beds are used mostly to grow sedums, a plant that is native to the area and requires little maintenance. The sedums absorb water and climatize the building, reducing storm water runoff and lowering heating and air conditioning needs (Horowitz, 2012; Whittinghill \& Bradley Rowe, 2012).

The roof also features a greenhouse and a hydroponic system that is arranged vertically to fully utilize the limited space. Hydroponics refers to a method of growing plants in nutrient enriched water rather than soil. Nutrient levels are maintained by adding liquid fertilizer. Hydroponic systems produce substantial amounts of food in small spaces, including indoors, and can be used to grow herbs, lettuce, spinach, kale, and other greens, as well as tomatoes, peppers, cucumbers, beans, okra and squash. Since no soil is needed, hydroponic production can be used even in areas where soil contamination may be an issue. The Van Ness Food Hub also incorporates an aquaponics system that combines growing fish (aquaculture) and growing vegetables without 
soil (hydroponics). The co-production of vegetables and fish creates significant water savings, high productivity levels, and reduced waste. The CAUSES aquaponic systems use only $10 \%$ of the water used in conventional agriculture and since the fish waste is used as plant fertilizer, very little waste is generated.

The University's Bertie Backus and PR Harris campuses are located in neighborhoods with lower urban density. Food production at both locations takes place in 30 foot x 85 foot hoop houses. The Bertie Backus location (see Figure 4) in Ward 5 is easily accessible by Metro and features three hoop houses, one with a hydroponic system, one with an aquaponic system, and one with a native plant nursery. The PR Harris location in Ward 8 features two large hoop houses with a hydroponic and an aquaponic system (see Figure 5).
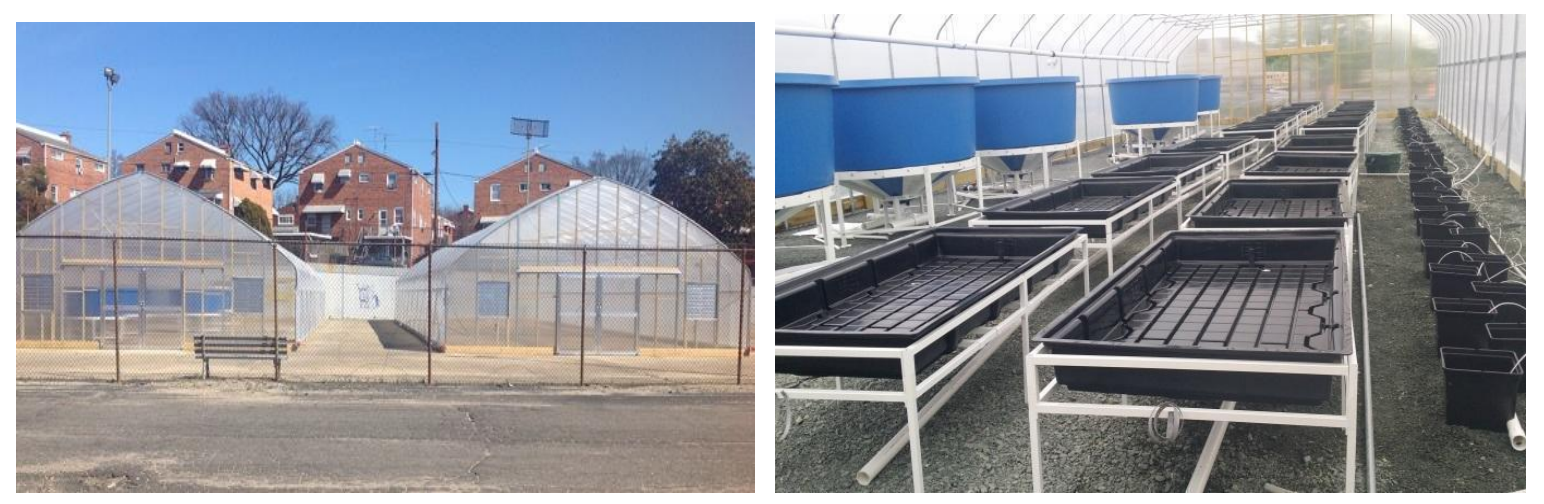

Figure 4. The UDC Urban Food Hub at Betrie Backus in Ward 5.
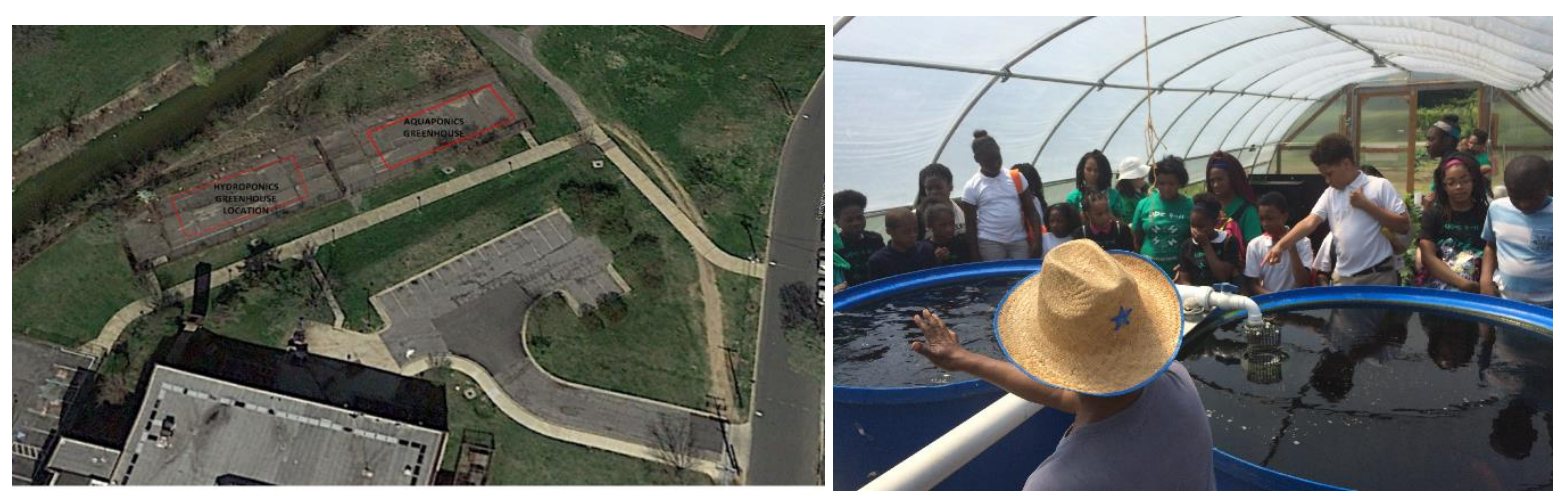

Figure 5. The UDC Urban Food Hub at PR Harris in Ward 8. The East Capitol Urban Farm is the UDC Urban Food Hub location in Ward 7 (see Figure 6). It features a community garden with 60 raised beds available to residents, a children's garden and play area, a nature trail, and an aquaponic system installed in a 30 foot $x 85$ foot hoop house. The D.C. housing authority made the three-acre site available to UDC for the purposes of developing a model for temporary urban farming that improves the condition of vacant land while future development decisions are being made.

The hydroponic and aquaponic systems pioneered by CAUSES are highly energy efficient and stable. An aeration device called the Flo-Vex, which is the patented invention of a UDC emeritus professor, is the key to efficiency (Kakovitch Industries, 2016). Another innovation is that all 
necessary components of the hydroponic and aquaponic systems are assembled on a metal skid for easy installation and maintenance (see Figure 7). Since experience with food production is limited in urban communities, the ease of installation and maintenance is an important consideration.
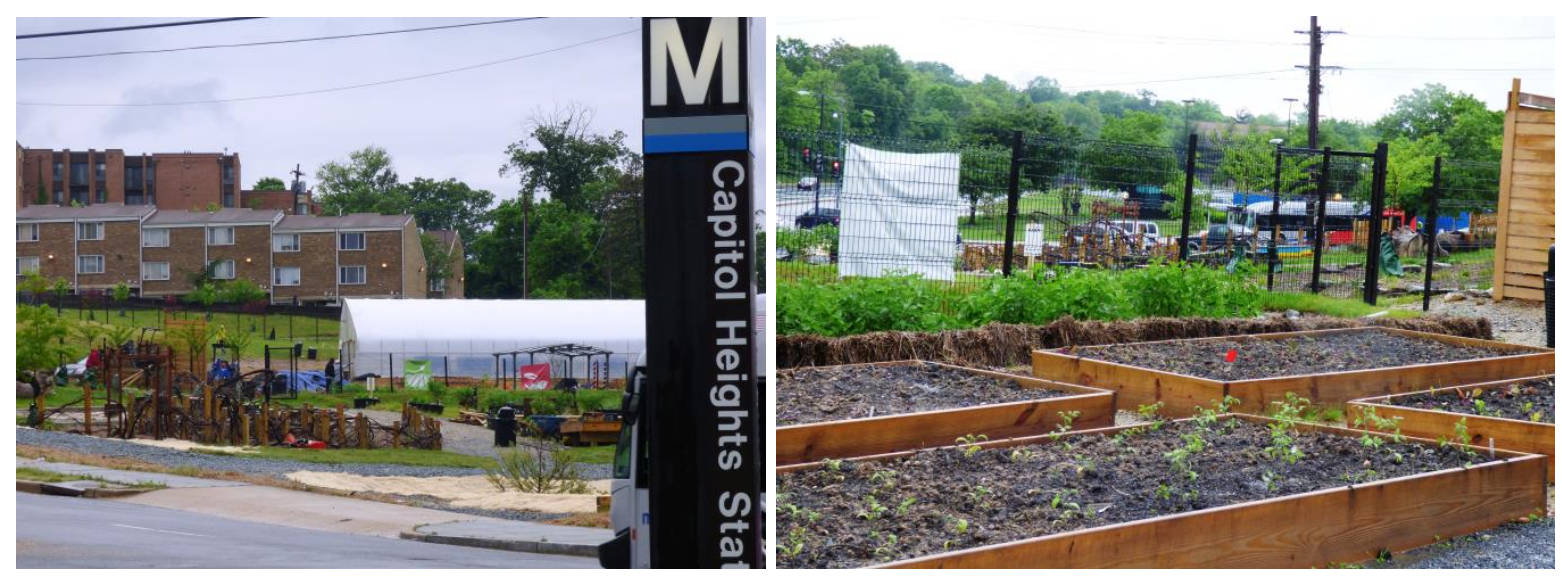

Figure 6. The East Capitol Urban Farm Food Hub in Ward 7

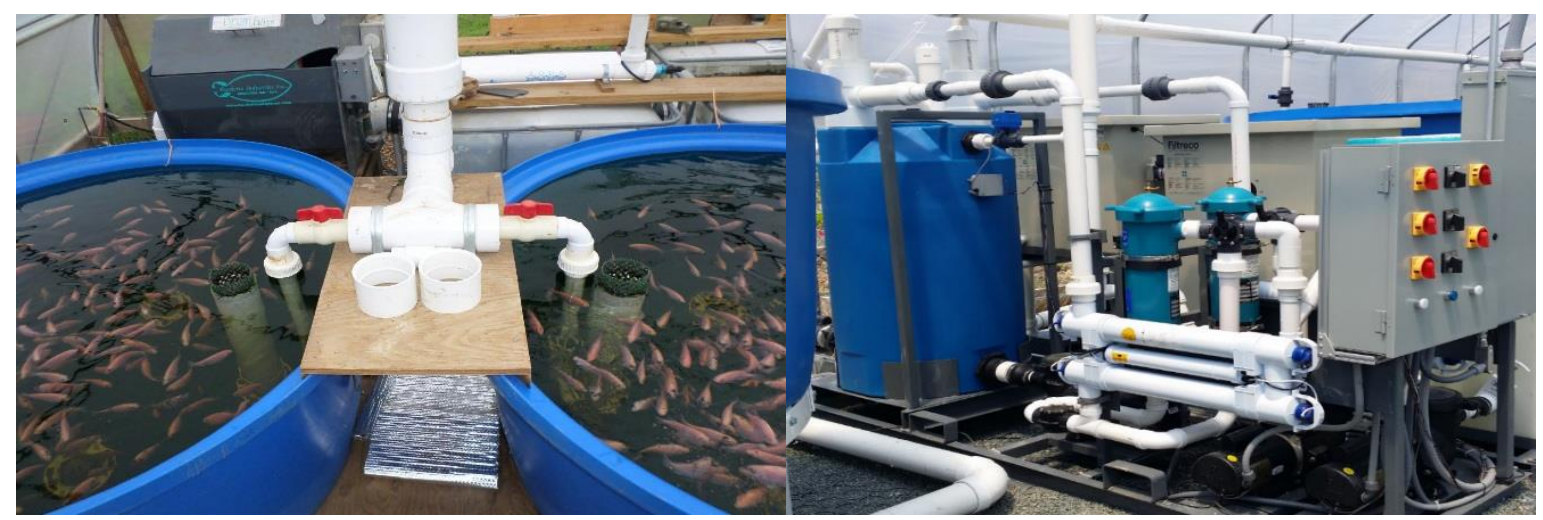

Figure 7. The Urban Aquaponic System at the UDC Urban Food Hubs in Wards 5, 7, and 8. An important part of the UDC capacity building mission, are training certificates, workshops, and demonstrations offered at the Urban Food Hubs and at the UDC Firebird Farm. Topics include introduction to urban agriculture, bio-intensive growing methods, hydroponic and aquaponic production, and integrative pest management; but also food safety, age appropriate nutrition, food preservation, composting, and rain garden design and maintenance.

\section{Food Preparation in Kitchens and Food Trucks}

Two main thrusts of activities comprise the food preparation component of the Urban Food Hubs-nutrition education and value added. To address them effectively each Urban Food Hub ideally has a well-equipped kitchen that serves as a teaching facility to improve information about healthy eating, healthy food preparation, and age-appropriate diets. The kitchens also serve as a business incubator for those interested in starting a catering business or turning tomatoes and peppers into salsa or other value-added products. The kitchens are designed to be functional and 
food safety compliant. Demonstration areas provide visible workspaces, and well-defined workstations for receiving, storing, preparing, preserving, and recycling.

Figure 8 shows the kitchen facility at the Van Ness Food Hub. Activities at the kitchens include nutrition education workshops, cooking classes, and food demonstrations. Certifications are offered in food handling, food safety, and food preservation like canning and pickling. The space can also be used to advance research on the determinants of safe food handling behaviors, risk perception, and cultural barriers that may impede the adoption of food safety and healthy eating habits.
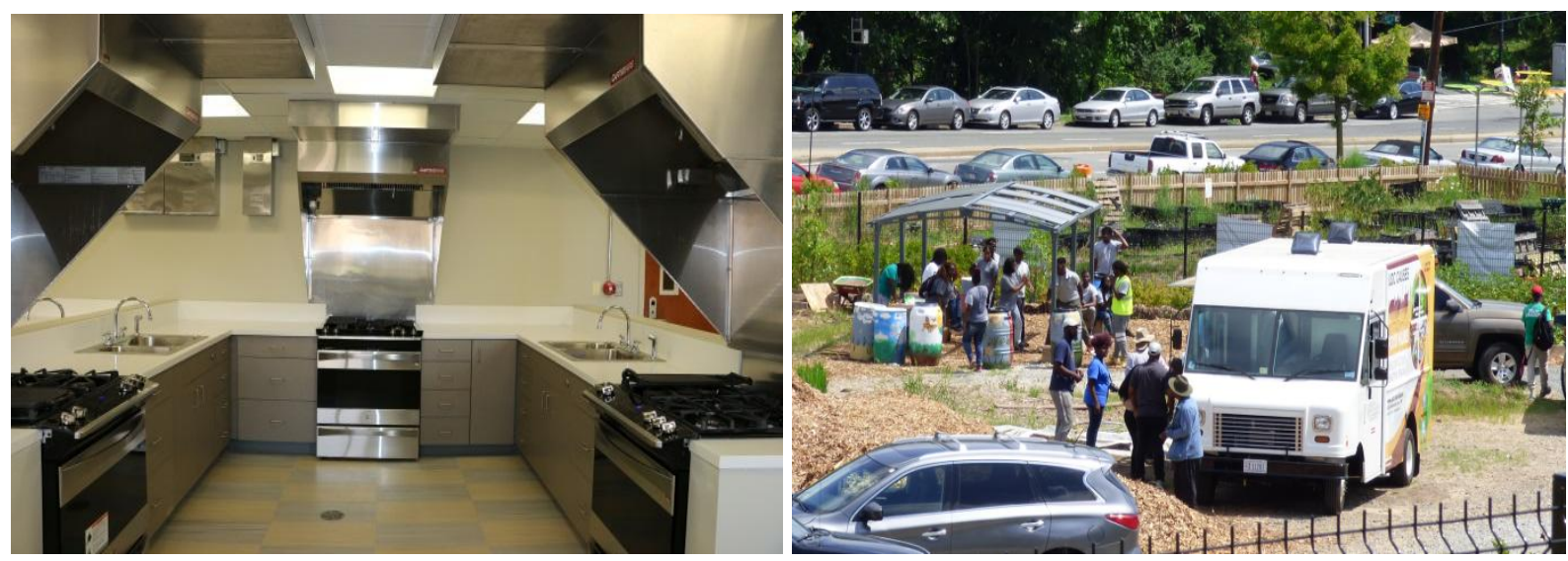

Figure 8. Van Ness Food Hub Kitchen and UDC Food Truck at East Capitol Urban Farm. Residents can also lease kitchen space to launch a catering or food-processing business. Nutrition education itself may also offer viable business opportunities. Recent legislative changes allow dieticians to prescribe a therapeutic diet. This is consistent with the increased focus on prevention, rather than treatment, which offers new opportunities to qualified dieticians and nutrition educators (Schaeffer, 2014; Anderson, Palombo, \& Earl, 1998).

Kitchens are expensive to build and operate. A more affordable option is a food truck that can serve as a mobile food demonstration and teaching facility in addition to serving as a mobile farmers market that takes fresh produce to food desert neighborhoods. The commercial kitchen at the UDC Firebird Farm is installed in a standardized container. This may be a viable option for some urban neighborhoods provided zoning regulations permit the installation of a container. CAUSES also partners with schools, churches, community centers, and non-profit organizations to ensure access to suitable kitchen facilities that are easily accessible to residents. To be successful, nutrition and food safety education must be culturally sensitive and aware of the social pressures associated with food preparation traditions and eating habits. One approach to improving nutritional health developed by a UDC nutrition and dietetics professor is to modify family recipes and culturally significant dishes to improve nutritional value without changing the taste (forthcoming). Another approach is to provide self-monitoring devices that offer feedback to improve awareness of food preparation and eating habits.

Much work remains to identify successful strategies to prepare food for improved public health and economic conditions. Food is not only about nutrition, but it is also an expression of cultural identity and ethnic pride. This makes the food preparation component of the Urban Food Hubs 
all the more important for the diverse urban neighborhoods they serve.

\section{Food Distribution and the Price Point Challenge}

A frequently-posed question is whether urban agriculture is commercially viable? The answer is, it depends. Growing demand for locally grown food and seasonal produce offers significant revenue potential (Pinchot, 2014). Yet high-revenue markets do not address the needs of urban food desert neighborhoods. These neighborhoods may not have the purchasing power to generate the revenue needed to cover the capital investment and operating expenses of an aquaponic or hydroponic system. To serve a low income local market may require a commitment to a socially responsible business model where a portion of the revenue generated from sales to high-end customers subsidizes lower revenue markets, or where some space is set aside as community space to supplement household incomes (Friedman, 2007; Golden, 2013; Philander \& Karriem, 2016).

One of the most lucrative food distribution models is contracting with high-end restaurants for micro-greens, edible flowers, lettuce mixes, and herbs. Micro-greens take less than two weeks from germination to harvest in a hydroponic greenhouse. If the greens are seeded every day, it is possible to establish a pattern of daily harvests. Greens sold to local restaurants require minimal packaging and labeling, whereas sales to grocery stores will require more extensive packaging and labeling that creates higher costs.

Ethnic crops offer another high-revenue market. The term refers to plants that are not native to the Americas. Given the diversity of restaurants and food traditions in metropolitan areas, ethnic crop niche markets offer unique opportunities for urban growers. Food tastings conducted by CAUSES indicate significant market opportunities in Washington D.C. especially for African crops. Particularly popular are garden eggs, kittely, hibiscus, and hot peppers (Afanchao, 2015).

Local farmers markets and Community Supported Agriculture (CSA) programs that sell directly to the end consumer are also popular distribution options. CSAs deliver fresh produce, typically once a week, to a central pickup location or directly to CSA member homes. Rather than charging a price per pound, CSAs charge customers a flat fee at the beginning of the growing season. In exchange, CSA members receive a weekly delivery of in-season produce. Some CSAs offer a lower price to customers willing to assist with crop maintenance, harvesting, and delivery (O'Hara \& Stagl, 2002). CSAs typically require minimal packaging. Produce is delivered in bags or boxes and CSA members exchange the empty container for a full one at the time of delivery. UDC operates a farmers market at the East Capitol Urban Farm and a farmers market and CSA at the Van Ness Food Hub. Other markets are expected to open during the 2017 growing season.

Generating sufficient revenue from sales to the end consumer can be challenging especially in low-income neighborhoods that are most in need of fresh food. The D.C. Produce Plus program (http://doh.dc.gov/service/produce-plus-program) expands the purchasing power of low-income neighborhoods. The program doubles the value of food stamps and Women, Infants, and Children (WIC) coupons if they are redeemed at a local farmers market. The Veggie Prescription program offers similar benefits. It works with local hospitals and community health centers to encourage health providers to offer prescriptions of fresh fruits and vegetables instead of medication. The veggie prescriptions are then redeemed at a local farmers market (Brody 2014). 
The Urban Food Hubs also support collaborative efforts including gleaning days and harvest collections. One such initiative, the City Orchard project, established a fruit orchard at the UDC Firebird Farm to grow a variety of berries, apples, and Asian pears for clients of a local food bank. The food bank, in turn, helps maintain the orchard through weekly volunteer days, which have the added benefit of introducing food bank clients to a farm often for the first time. Collaborations with local schools, culinary institutes, and other hospitality sector partners also expand food distribution options. For example, a local green roof business estimates that $50 \%$ of its revenue comes not from food production but from catering and health and wellness events.

Food distribution-related programs offered by CAUSES include entrepreneurship classes, market research to assess opportunities in the food and hospitality sector, and research on the delivery preferences of various demographics. The skills associated with fish and produce production, and with the value-added from food processing and preservation, are only of benefit if they find markets that generate revenue and living wages.

\section{Closing the Loop through Waste and Water Recovery}

Waste and water management are essential components of the UDC Urban Food Hubs. Given the land-use pressure in growing metropolitan areas like Washington D.C., this component can add valuable positive externalities that add to the economic bottom line of food production and value-added food preparation. For example, food and horticulture plants that are growing on green roofs, in community gardens, and in rain gardens absorb water and urban farms add permeable surfaces to the urban scape. This can meaningfully reduce storm water runoff and reduce the pressure on storm-water systems that are often outdated and well below current capacity needs. Urban agriculture can therefore mitigate flooding risks and improve urban resiliency. The term resilience refers to the ability of communities to cope with disruptive events like natural disasters and to recover more quickly from the negative impacts of a disaster (Meerow, Newell, \& Stults, 2016; Prior \& Roth, 2013; Wheater \& Evans, 2009).

Vegetable plants have relatively high nutrient needs. It may therefore be necessary to capture the water runoff from urban agriculture systems and reduce water-soluble nutrients before the water run-off is released into the storm water system (Niemczynowicz, 1999). The Van Ness Food Hub captures the water runoff from the food-producing green roof and stores it in cisterns for reuse in irrigation systems that maintain plantings around the center of the campus (see Figure 9). This kind of water management adds value that is not captured in the revenue generated by food products. A number of cities also offer storm water credits to incentivize water capture and reuse (Friedrich, 2016).

Water Capture at the Van Ness Food Hub and Soil Mitigation at East Capitol Urban Farm. The design, installation, and maintenance of rain gardens and green roofs offers viable business opportunities and improves the aesthetics of the urban scape. A particularly innovative rain garden is a rice paddy that was installed at the East Capitol Urban Farm (see Figure 10). The small rice field grows organic rice in a flood-prone area. This generates dual benefits from storm water management and sustainable rice production. In addition, the innovative rain garden adds to the aesthetics of the site. 
The design, installation, and maintenance of rain gardens and green roofs offers viable business opportunities and improves the aesthetics of the urban scape. A particularly innovative rain garden is a rice paddy that was installed at the East Capitol Urban Farm (see Figure 10). The small rice field grows organic rice in a flood-prone area. This generates dual benefits from storm water management and sustainable rice production. In addition, the innovative rain garden adds to the aesthetics of the site.
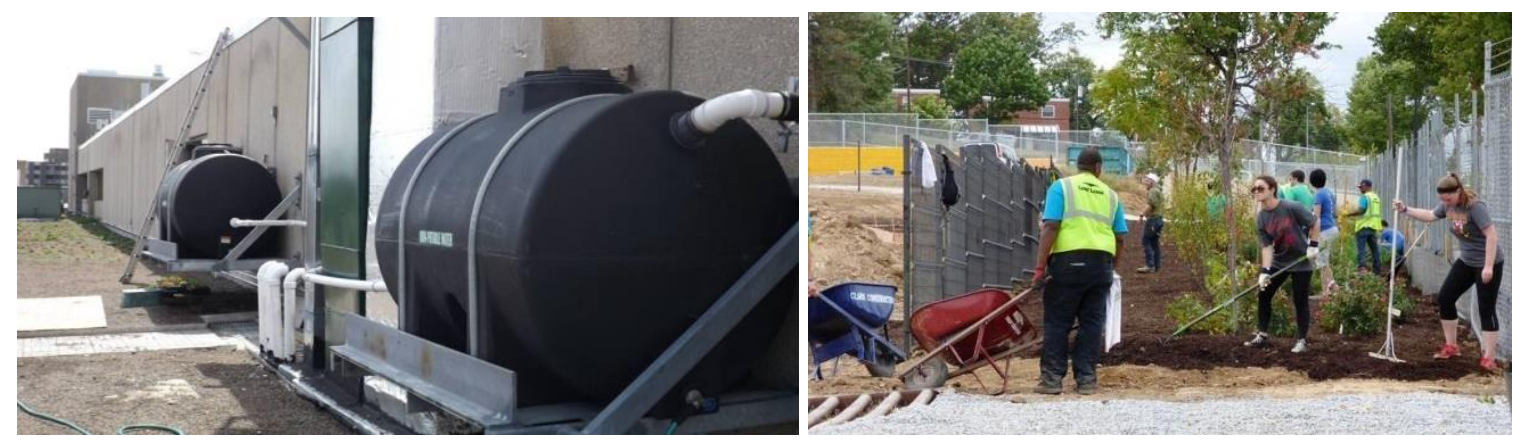

Figure 9. Water Capture at the Van Ness Food Hub and Soil Mitigation at East Capitol Urban Farm.
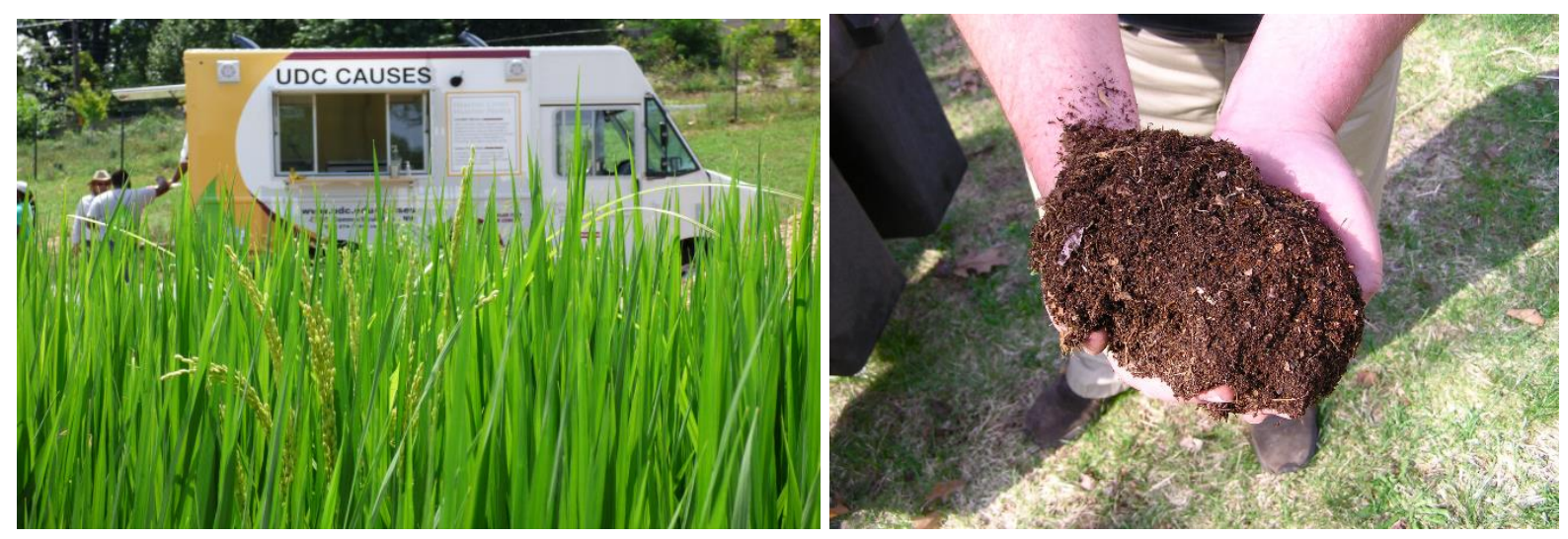

Figure 10. The Rain Garden Rice Paddy at East Capitol Urban Farm and Compost for Soil Mitigation. Urban soils are often contaminated and may require soil amendments before they are suitable for food production. Composting is key and each of the urban food hubs has a small composting site where plant and food waste can be turned into healthy soil. A recent business start-up in the D.C. area is Compost Taxi. For a monthly fee, Compost Taxi picks up food waste from residential households and composts it to support urban agriculture initiatives.

The social benefits of green-infrastructure improvements also go beyond soil and water management benefits. Adding green space to health facilities, for example, improved the performance of medical staff and the healing and recovery process of patients (Guenther \& Vittori, 2013). Other social benefits include improved neighborhood safety, better walkability, more exercise, and added public space where neighbors can socialize (Ackerman et al., 2014; Chiffoleau, Millet-Amrani \& Canard, 2016; Daiggaer, 2009; Dixon et al., 2007; Gallet, 2011) As the Urban Food Hubs continue to evolve, each hub may eventually be equipped with an alternative energy source that takes the Urban Food Hubs off the grid and turns them into 
resiliency hubs that can secure food, water, and energy during times of crisis. This resilience model is already under development at the UDC Firebird Farm. It features a solar-powered groundwater well, a containerized aquaponic system and kitchen, and a solar powered walk-in refrigerator.

The Urban Food Hubs also enhance the learning opportunities of UDC students. They serve as a common focal point for service learning, student and faculty research, leadership development, and professional networking. Students can enroll in the certificate courses and workshops offered through the University's land-grant programs to prepare them for success as entrepreneurs in the local food and green infrastructure economy.

\section{Investing in Urban Capacity Building}

Metropolitan universities have long been at the forefront of investing in surrounding communities. Capacity building investments include renovation and reuse of residential properties, business incubators, neighborhood storefronts, and more. Frequently these initiatives put un- and under-utilized buildings back in use as resident halls, offices, classrooms, and businesses (Drucker \& Goldstein, 2007; O’Hara, 2001; Rucinski, 2001).

The UDC Urban Food Hubs expand this capacity building role to include university-owned food production, food processing, and green infrastructure facilities. Similar to a business incubator that makes space, equipment, and shared services available to business start-ups, the Urban Food Hubs make an upfront investment in the urban food and green infrastructure sector (Saegert, 2006). This improves the likelihood of success for start-up businesses that would find it difficult to make the capital investment necessary to install a hydroponic or aquaponic system, a green roof, or a commercial kitchen.

Even less capital-intensive production methods that utilize raised bed gardens may require considerable up front investments. When land that was previously used as a building site, is converted to agricultural land, the up-front soil remediation and site preparation costs can be substantial. The Urban Agriculture toolkit published by the USDA tallies the projected investment at $\$ 100,000$ to $\$ 250,000$ for a half-acre parcel of land (USDA, 2016). The kitchen facilities associated with the food preparation component of the Urban Food Hubs can be even more costly unless a pre-existing kitchen facility is available for use or renovation.

The UDC Urban Food Hubs initiative has begun to make the necessary investments to turn food desert neighborhoods into thriving neighborhoods. A pilot project to test the University's entrepreneurship based model was launched at the UDC Firebird Farm where a group of students built and managed a hydroponic system installed in a 30-foot x 60-foot hoop house. The students successfully produced head lettuce and basil for sale at local farmers markets and the model is now being transferred to the UDC Urban Food Hubs. The Hubs currently under development feature four hydroponic and four aquaponic facilities, two commercial kitchens, and a food truck. Funding for the Urban Food Hubs comes from a sustainable development grant of the District of Columbia, from the Anacostia Economic Development Corporation, and from the University's own capital funds. In the tradition of land-grant universities, the UDC College of Agriculture Urban Sustainability and Environmental Sciences (CAUSES) provides training and technical assistance for the development, implementation, and operation of the businesses launched at the 
Urban Food Hubs. The hubs thus offer a model for business development from the ground up that identifies local entrepreneurs who wish to utilize the business opportunities the hubs offer. Prospective entrepreneurs can use an on-line application process to apply for the use of the facilities. A review panel interviews applicants to select the most promising entrepreneurs. Since the new business start-ups will have to carry only operating expenses, their financial viability and future expansion potential should be improved. By investing in the Urban Food Hubs, UDC expects to improve the success rate of the urban businesses it incubates.

The model has also proven to offer additional business development opportunities in the technology sector. A UDC computer science professor and an emeritus professor are collaborating to develop a sensor system that optimizes the productivity of the aquaponic and hydroponic facilities through a National Science Foundation Small Business Technology Transfer (STTR) grant (Clearton, 2017). The STTR program provides funds for small businesses to conduct research and development (R\&D) on technology innovations that have the potential to be commercially successful and benefit society. Early indications suggest the Urban Food Hubs can galvanize neighborhood activity and provide social and environmental benefits that go beyond the core objectives of spurring economic development and improving health outcomes. The following section highlights the social and environmental benefits of the food hubs.

\section{Assessing Broader Social and Environmental Impacts}

The UDC Urban Food Hubs offer a model to diversify and localize the food and green infrastructure economy of metropolitan communities. While the economic viability of the Urban Food Hubs will depend on the specific business model and site characteristics of each hub, the social benefits of improved health outcomes of underserved urban populations are indisputable. Seeing how food is grown can be an effective catalyst for adopting more healthful eating habits and for reducing the public health expenditures associated with food-related illness. Michigan State University's Cooperative Extension Service identified seven benefits of locally grown food that are not captured in the food price. Locally grown food is: (a) more flavorful; (b) reconnects us with the seasons; (c) is more nutrient dense; (d) supports the local economy; (e) benefits the environment; (f) promotes a safer food supply; and (g) connects consumers and growers which improves awareness of where food comes from (Halweil, 2002; Klavinski, 2013). A report published by the University of California Davis (2015), also attributes considerable social, health, and economic impacts to urban agriculture, and an MIT study documents the economic impact of urban aquaponics (Goodman, 2011). The field of ecological economics offers especially useful examples for calculating the value of the social and environmental side benefits of economic activity (O'Hara, 1996; 2004; 2014). The USDA Regional Food Hub Resource Guide also illustrates economic, social, and environmental impacts (Barham et al., 2012).

Some of the benefits of locally grown food will depend on the specific production methods applied. Some growers, for example, may be committed to growing seasonal food plants while others will grow the same salad mix year around. Environmental benefits may vary with the energy used for food production. Almost regardless of the specific production methods, the Urban Food Hubs reduce water use and improve storm water management. Many cities have an aging water infrastructure that is at capacity and will benefit from the reduced water runoff associated with the Urban Food Hubs. The benefits of reduced transportation and improved freshness also apply across the board, regardless of the specific production method used. The 
urban food hubs can also improve the aesthetics of a neighborhood. Raised bed gardens, trellises, and vertical growing systems can bring tremendous enhancements to an urban neighborhood. Other benefits may result from the reuse of unused or underutilized buildings that can be successfully repurposed for indoor food production.

Much has been written about how to measure the quality of life of urban communities and the complex economic, social, and environmental impacts of sustainable development strategies (Agudelo-Vera et al., 2011; Birch \& Wachter, 2008; Burton, 2009; Costanza et al., 2007; Marans \& Kweon, 2011; Paul, Magee, Scerri, \& Steger, 2015; Sirgy \& Cornwell, 2002; Smit, Nasar, \& Ratta, 1996; Vollmer, 2011; Wheeler \& Beatley, 2014). A practical approach that brings the social and environmental impacts of economic development into view is the Five Pillars of Economic Development model pioneered by the author (Kakovitch \& O'Hara, 2014; O'Hara \& Vazques, 2006). This model argues that the key to long-term economic success lies in focusing on the needs and assets of local communities. This requires closer attention to those factors that undergird successful economic development rather than to economic indicators themselves. While economic indicators like the numbers of jobs or GDP per capita provide a snapshot of the impact of past actions, the Five Pillars focus on future economic development potential. By tracking those factors that are commonly considered external to the purview of economics, communities can be more pro-active in their development decisions. The Five Pillar categories that capture long-term economic success are: (a) health; (b) education; (c) environmental quality; (d) social and cultural amenities; and (e) access to information and transportation (see Figure 11). Table 2 offers a sample of indicators that can capture trends in the Five Pillar areas. Tracking the impact of the Urban Food Hubs on these indicators provides a measure of the longterm economic development impact of the hubs.

\section{Economic Development}

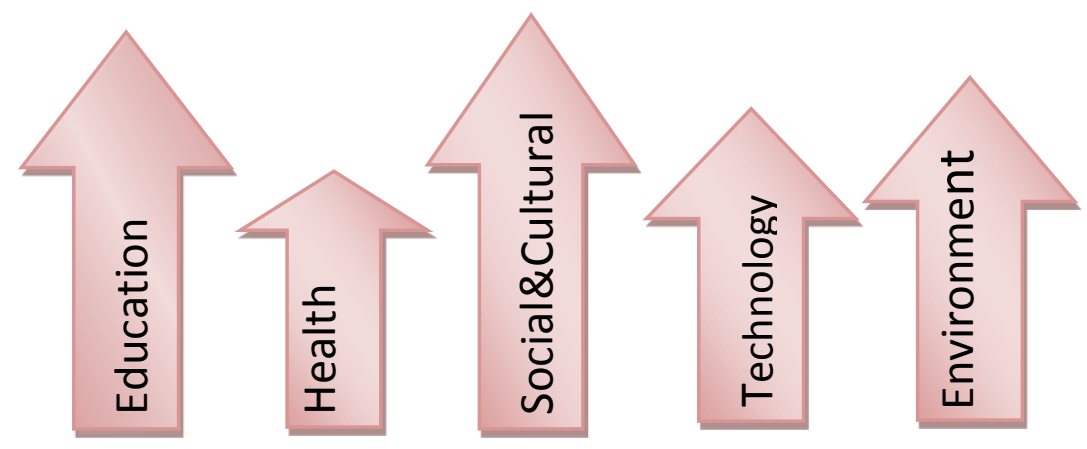

Figure 11. The Five Pillars of Economic Development. Economic development strategies that focus on the Five Pillars depend on local information and local knowledge. The knowledge of credentialed experts that uses aggregated data and often assumes that solutions are transferrable from one community to another may be useful, but not sufficient. Such aggregated information can create distortions that underestimate local purchasing power and other local assets. What is needed instead is the knowledge of local experts who can give voice to local context conditions, development barriers, and assets. Such local knowledge is typically sparse, yet it is the very basis for identifying viable markets and resources that are often overlooked. 
University decision makers must look beyond the usual circle of stakeholders and outside their comfort zone to ensure research agendas and capacity building agendas are shaped by a commitment to bring the life worlds (translated from Habermas term Lebenswelt; Habermas, Habermas, \& McCarth y,1985) of local communities and non-credentialed local experts into focus. Without the engagement of local experts, local contexts will be misrepresented, underrepresented, or omitted altogether (O’Hara, 1996; Raja \& Diao, 2016; Hacker et al., 2012). A Five Pillars study for Washington D.C. is currently under way and will be released in 2017.

Table 2

Selected Indicators of the Five Pillars of Economic Development

\begin{tabular}{|cc|}
\hline Indicator Category \\
\hline Education \\
\hline$\bullet$ & \% of population with one or more year of college \\
$\bullet$ & Public high school graduation rate \\
$\bullet$ & Student:teacher ratio in public schools \\
\hline Health & Achievement test scores (ACT/SAT) of high school seniors \\
\hline$\bullet$ & Life expectancy \\
$\bullet$ & \# of physicians per 1,000 of the population \\
$\bullet$ & \% of population that is obese \\
\hline - & of population with diabetes \\
\hline$\bullet$ & \# of full service grocery stores per 100 of population \\
$\bullet$ & \# of sit-down restaurants \\
organizations \\
\hline$\bullet$
\end{tabular}

Metropolitan universities are ideally positioned to take on the role of facilitating a local and regional discourse about pathways to long-term sustainable development. This may take the form of stakeholder meetings, listening sessions, neighborhood meetings, and other forms of dialogue with a broad range of individuals and organizations that offer a perspective on local needs, assets, opportunities, and deficits. The Urban Food Hubs stand in the tradition of the Cooperative 
Extension Service of United States land-grant universities and offer a space for formal and informal discourse applied to a metropolitan context.

\section{Conclusion}

The Urban Food Hubs of the College of Agriculture, Urban Sustainability, and Environmental Sciences (CAUSES) of the University of the District of Columbia (UDC) offer a model for capacity building that is committed to creating a local economy that improves the economic, social, and environmental conditions of underserved urban communities. The Urban Food Hubs are designed to improve access to fresh food, reduce health deficits, and create jobs. Each food hub consists of four components that link economic, social, and environmental impacts.

The four components offer four distinct types of business development through high intensity food production on green roofs, raised bed gardens, and hydroponic and aquaponic facilities; food preparation that adds value to locally grown food and improves public health; innovative food distribution models that improve access to high quality affordable food through farmers markets, food trucks, and CSAs; and waste and water management through composting, reduced storm water run-off, and green infrastructure improvements.

The metropolitan area of Washington D.C. is growing. The Urban Food Hubs must therefore be competitive in an environment of intense land use pressure. Counting external benefits in addition to core mission of improving food security and creating jobs is therefore of paramount importance. Some more tangible benefits include reduced food-related illnesses and improved storm water management. Some less tangible ones include improved neighborhood aesthetics, stronger civic engagement and neighborhood safety. By making an upfront investment in the Urban Food Hubs, the UDC is creating the capacity for improved food access, health, and economic development in underserved neighborhoods in the nation's capital.

Beyond applicability for Washington D.C., the Urban Food Hubs can serve as a model to improve the quality of life and economic opportunity of urban communities across the nation. The Urban Food Hubs thus have a larger agenda: to create a network of sustainable and resilient local food systems that advance the economic, social/cultural, and environmental/physical benefits. The long-term sustainable development success of metropolitan communities depends on developing such resilient local economies. As urbanization continues globally, food and water security cannot be addressed without solutions that include urban communities and reimagine them as hubs for a comprehensive, sustainable food system close to where the majority of consumers live-in metropolitan communities.

\section{References}

Ackerman, K., Dahlgren, E., \& Xu, X. (2012). Sustainable urban agriculture: Confirming viable scenarios for production.

Ackerman, K., Conard, M., Culligan, P., Plunz, R., Sutto, M. P., \& Whittinghill, L. (2014). Sustainable food systems for future cities: The potential of urban agriculture. The economic and social review, 45(2, Summer):189-206. 
Abel, J., \& Dietz, R. (2012). How Colleges and Universities Can Help Their Local Economies. Liberty Street Economics. Federal Reserve Bank of New York. Feb.13

Afanchao, Y. (2015). Ethnic Crops and Market Receptivity. Research Report. Center for Urban Agriculture and Gardening Education. University of the District of Columbia. College of Agriculture, Urban Sustainability and Environmental Sciences. Washington D.C.

Agudelo-Vera, C. M., Mels, A. R., Keesman, K. J., \& Rijnaarts, H. H. (2011). Resource management as a key factor for sustainable urban planning. Journal of environmental management, 92(10), 2295-2303. https://doi.org/10.1016/j.jenvman.2011.05.016

Anderson, J., Palombo, R, \& Earl, R. (1998). Position of the American Dietetic Association: the role of nutrition in health promotion and disease prevention programs. Journal of the American Dietetics Association. 98(2), 205-208. https://doi.org/10.1016/S0002-8223(98)00052-2

Barham, J., Tropp, D., Enterline, K., Farbman, J., Fisk, J., \& Kiraly, S. (2012). Regional food hub resource guide (No. 145227). Retrieved from

https://www.ams.usda.gov/sites/default/files/media/Regional\%20Food\%20Hub\%20Resource\%2 0Guide.pdf http://dx.doi.org/10.9752/MS046.04-2012

Barthel, S., \& Isendahl, C. (2013). Urban gardens, agriculture, and water management: Sources of resilience for long-term food security in cities. Ecological Economics, 86, 224-234. https://doi.org/10.1016/j.ecolecon.2012.06.018

Baum-Snow, N., \& Pavan, R. (2012). Understanding the city size wage gap. The Review of economic studies, 79(1), 88-127. https://doi.org/10.1093/restud/rdr022

Berube, A. \& Holmes, N. (2015, March 17). Some cities are still more equal than others - an update. Brookings Metropolitan Opportunities Series. Retrieved from

https://www.brookings.edu/research/some-cities-are-still-more-unequal-than-others-an-update/

Birch, E., \& Wachter, S. (2008). Growing greener cities: Urban sustainability in the twenty-first century. University of Pennsylvania Press. https://doi.org/10.9783/9780812204094

Brody, J. (2014). Prescribing Vegetables, Not Pills. New York Times Blog. Dec. 1. Retrieved from https://well.blogs.nytimes.com/2014/12/o1/prescribing-vegetables-not-pills/?_r=o

Brown, K. H., \& Jameton, A. L. (2000). Public health implications of urban agriculture. Journal of public health policy, 21(1), 20-39. https://doi.org/10.2307/3343472

Burton, C. (2009). Building Resilient Communities: risk management and response to natural disasters through social funds and community-driven development operations. Research Report. The World Bank, Washington D.C.

Canning, P., Charles, A., Huang, S., Polenske, K., \& Waters, A. (2010). Energy use in the US food system. United States Department of Agriculture. Economic Research Service. 
Chiffoleau, Y., Millet-Amrani, S., \& Canard, A., (2016), From Short Food Supply Chains to Sustainable Agriculture in Urban Food Systems: Food Democracy as a Vector of Transition, Agriculture, 6(4), 57. https://doi.org/10.3390/agriculture6040057

Clearton LLC (2017). Project Deep Flow: Automation and Optimization of Aquaponics for Urban Food Production. SBIR/STTR Award 1521153 Phase I Report, January 3.

Cook, J., Frank, D., Levenson, S., Neault, N., Heeren, T., Black, M., ... \& Chilton, M. (2006). Child food insecurity increases risks posed by household food insecurity to young children's health. The Journal of Nutrition, 136(4), 1073-1076.

Costanza, R., Fisher, B., Ali, S., Beer, C., Bond, L., Boumans, R., \& Gayer, D. E. (2007). Quality of life: An approach integrating opportunities, human needs, and subjective well-being. Ecological economics, 61(2), 267-276. https://doi.org/10.1016/j.ecolecon.2006.02.023

Daigger, G. T. (2009). Evolving urban water and residuals management paradigms: Water reclamation and reuse, decentralization, and resource recovery. Water environment research, 81(8), 809-823. https://doi.org/10.2175/106143009X425898

District of Columbia Department of Health. (2013). District of Columbia community health needs assessment. Vol 1. Retrieved from http://doh.dc.gov/sites/default/files/dc/sites/doh/page_content/attachments/2nd\%20Draft\%20CH NA\%20\%28v4\%202\%29\%2006\%2004\%202013\%20-\%20Vol\%201.pdf

Dixon, J., Omwega, A. M., Friel, S., Burns, C., Donati, K., \& Carlisle, R. (2007). The health equity dimensions of urban food systems. Journal of Urban Health, 84(1), 118-129. https://doi.org/10.1007/s11524-007-9176-4

Drucker, J., \& Goldstein, H. (2007). Assessing the regional economic development impacts of universities: a review of current approaches. International Regional Science Review, 30 (1): 2046. https://doi.org/10.1177/0160017606296731

Florida, R. (2005). Cities and the creative class. Routledge. New York.

Friedman, H. (2007). Scaling up: Bringing public institutions and food service corporations into the project for a local, sustainable food system in Ontario. Agriculture and Human Values, 24(3), 389-398. https://doi.org/10.1007/s10460-006-9040-2

Gallet, D. (2011). The Value of Green Infrastructure: A Guide to Recognizing Its Economic, Environmental and Social Benefits. Proceedings of the Water Environment Federation, 2011(17), 924-928. https://doi.org/10.2175/193864711802639741

Golden, S. (2013). Urban Agriculture Impacts: Social, Health, and Economic: An Annotated Bibliography. 
Goodman, E. R. (2011). Aquaponics: community and economic development. Doctoral dissertation, Massachusetts Institute of Technology. Retrieved from http://hdl.handle.net/1721.1/67227

Gorgolewski, M., Komisar, J., \& Nasr, J. (2011). Carrot City: Designing for Urban Agriculture.

Guenther, R, \& Vittori, G. (2013) Sustainable Healthcare Architecture. New Jersey. John Wiley $\&$ Sons Inc.

Habermas, J., Habermas, J., \& McCarthy, T. (1985). The theory of communicative action (Vol. 2). Beacon press.

Hacker, K., Tendulkar, S. A., Rideout, C., Bhuiya, N., Trinh-Shevrin, C., Savage, C. P., ... \& DiGirolamo, A. (2012). Community capacity building and sustainability: outcomes of community-based participatory research. Progress in community health partnerships: research, education, and action, 6(3), 349. https://doi.org/10.1353/cpr.2012.0048

Halweil, B. (2002). Home grown: The case for local food in a global market (Vol. 163). Worldwatch Institute.

Horowitz, C. (2012). Looking Up: How Green Roofs and Cool Roofs Can Reduce Energy Use, Address Climate Change, and Protect Water Resources in Southern California.

James, P., Magee, L., Scerri, A., \& Steger, M. (2015), Urban sustainability in theory and practice: circles of sustainability. Routledge.

Kakovitch Industries. (2016). The Flo-Vex Company. Retrieved from http://www.flo-vex.com

Kakovitch, T. \& O'Hara, S. (2014). Physics and the New Economy. HRD Press. Amherst, MA

Klavinski, R. (2013) The Benefits of Locally Grown Food. Michigan State University Cooperative Extension Service. Retrieved from http://msue.anr.msu.edu/news/7 benefits_of_eating_local_foods

Li, D., Bou-Zeid, E., \& Oppenheimer, M. (2014). The effectiveness of cool and green roofs as urban heat island mitigation strategies. Environmental Research Letters, 9(5), 055002. https://doi.org/10.1088/1748-9326/9/5/055002

Lovell, S. T. (2010). Multifunctional urban agriculture for sustainable land use planning in the United States. Sustainability, 2(8), 2499-2522. https://doi.org/10.3390/su2082499

Marans, R. W., \& Kweon, B. S. (2011). The quality of life in metro Detroit at the beginning of the millennium. In: Investigating quality of urban life (pp. 163-183). Springer Netherlands. https://doi.org/10.1007/978-94-007-1742-8_7 
Meerow, S., Newell, J. P., \& Stults, M. (2016). Defining urban resilience: A review. Landscape and urban planning, 147, 38-49. https://doi.org/10.1016/j.landurbplan.2015.11.011

National Research Council. (1995). Colleges of agriculture at the land grant universities: A profile. National Academies Press.

New Economics Foundation (2014). Plugging the Leaks: Local Economics Development as if people and the planet mattered. Retrieved from http://www.pluggingtheleaks.org/about

Niemczynowicz, J. (1999). Urban hydrology and water management-present and future challenges. Urban water, 1(1), 1-14. https://doi.org/10.1016/S1462-0758(99)00009-6

Nord, M., Coleman-Jensen, A., Andrews, M., \& Carlson, S. (2010)

Household Food Security in the United States, 2009. ERR-108, U.S. Dept. of Agriculture, Econ. Res. Serv.

O'Hara, S. (1995). Sustainability: social and ecological dimensions. Review of Social Economy, 53(4), 529-551. https://doi.org/10.1080/00346769500000017

O’Hara, S. U. (1996). Discursive ethics in ecosystems valuation and environmental policy. Ecological Economics, 16(2), 95-107. https://doi.org/10.1016/0921-8009(95)00085-2

O'Hara, S. U. (1997). Toward a sustaining production theory. Ecological Economics, 20(2), 141154. https://doi.org/10.1016/S0921-8009(96)00024-9

O'Hara, S. U. (2001). Urban development revisited: the role of neighborhood needs and local participation in urban revitalization. Review of Social Economy, 59(1), 23-43.

https://doi.org/10.1080/00346760110036265

O’Hara, S. (2004). Economics in Context. in: M. Jochimsen, S. Kesting, U. Knobloch (Eds.) Lebensweltökonomie (pp. 103-128). Bielefeld, Germany: Kleiner Verlag,.

O’Hara, S. (2014). Everything needs care: Toward a context-based economy. In M. Bjørnholt \& A. McKay (Eds.) Counting on Marilyn Waring: New Advances in Feminist Economics (pp. 3755). Bradford, ON: Demeter Press.

O'Hara, S. (2015). Food security: the urban food hub solution. Solutions, 6(1), 42-52. Retrieved from https://www.thesolutionsjournal.com/article/food-security-the-urban-food-hubs-solution/

O’Hara, S. (under review). The Urban Aquaponics Tool Kit. United States Department of Agriculture. National Institute of Food and Agriculture.

O’Hara, S. U., \& Stagl, S. (2002). Endogenous preferences and sustainable development. The Journal of Socio-Economics, 31(5), 511-527. https://doi.org/10.1016/S1053-5357(02)00134-8 
O’Hara, S., \& Vazquez, J. (2006). The Five Pillars of Economic Development: A Study of Best Practices for the Roanoke Valley. Research Report, Roanoke College, Salem, VA.

Paul, J., Magee, L., Scerri, A., \& Steger, M. (2015) Urban Sustainability in Theory and Practice: Circles of Sustainability. London: Routledge.

Philander, F. R., \& Karriem, A. (2015, December 10). Assessment of urban agriculture as a livelihood strategy for household food security: An appraisal of urban gardens in Langa, Cape Town. International Journal of Arts \& Sciences, 7(5), 327-338.

Pinchot, A. (2014). The Economics of Local Food Systems: A literature review of the production, distribution and consumption of local food. Minneapolis, MN: University of Minnesota. Retrieved from http://conservancy.umn.edu/handle/11299/171637

Porter, M. E. (2007), Colleges and Universities and Regional Economic Development: A Strategic Perspective, Futures Forum, Forum for the Future of Higher Education and NACUBO, 41-44.

Prior, T., \& Roth, F. (2013). Disaster, resilience and security in global cities. Journal of Strategic Security, 6(2), 59. https://dx.doi.org/10.5038/1944-0472.6.2.5

Raj, S., Raja, S., \& Dukes, B. A. (2016). Beneficial but Constrained: Role of Urban Agriculture Programs in Supporting Healthy Eating Among Youth. Journal of Hunger and Envrionmental Nutrition, 1-23. https://dx.doi.org/10.1080/19320248.2015.1128865

Raja, S., \& Diao, C. (2016). A community-led view of urban agriculture policy-making in the United States. Urban Agriculture Magazine, 31, 18-24. Retrieved from http://www.ruaf.org/community-led-urban-agriculture-policy-making-view-united-states

Royte, E. (2015). Urban Agriculture is booming but what does it really mean: The benefits of city-based agriculture go far beyond nutrition. ENSIA Magazine. April. 27.

Rucinski, L. (2001). The Union College/Schenectady Initiative Revives Neighborhood. College Planning \& Management, 4(3), 58-60.

Saegert, S. (2006). Building civic capacity in urban neighborhoods: An empirically grounded anatomy. Journal of Urban Affairs, 28(3), 275-294. https://doi.org/10.1111/j.14679906.2006.00292.x

Schaeffer, J. (2014). Therapeutic diet ordering privileges: What the CMS final rule says, to whom it applies, and what RDs and other nutrition professionals think about it. Today's Dietician, 16(10), 48. Retrieved from http://www.todaysdietitian.com/newarchives/100614p48.shtml

Shuman, M. (2015). The Local Economy Solution: How Innovative, Self-financing "pollinator" Enterprises Can Grow Jobs and Prosperity. White River Junction, VY: Chelsea Green 
Publishing.

Shuman, M. (2002) Going Local: Creating Self-Reliant Communities in a Global Age. New York: Routledge.

Siegfried, J., Sanderson, A. \& McHenry, P. (2007). The Economic Impact of Colleges and Universities. Economics of Education Review, 26(5), 546-558.

https://doi.org/10.1016/j.econedurev.2006.07.010

Sirgy, M. J., \& Cornwell, T. (2002). How neighborhood features affect quality of life. Social indicators research, 59(1), 79-114. https://doi.org/10.1023/A:1016021108513

Smit, J., Nasr, J., \& Ratta, A. (1996). Urban agriculture: food, jobs and sustainable cities. New York, USA: United Nations Development Programme. 35-37.

United Nations Development Program (1996). Urban Agriculture - Food, Jobs and Sustainable Cities. New York: United Nations Development Programme Publication Series for Habitat II, Volume One.

United States Bureau of the Census. (2014, July 10). Population. Retrieved from http://www.census.gov/topics/population.html

United States Department of Agriculture, Agricultural Research Service. (2014). USDA Food and Nutrient Database for Dietary Studies 2011-2012. Food Surveys Research Group Home Page. Retrieved from http://www.ars.usda.gov/ba/bhnrc/fsrg

United States Department of Agriculture, National Institute of Food and Agriculture. (2014) Cooperative Extension History. Retrieved from https://nifa.usda.gov/cooperative-extensionhistory

United States Department of Agriculture, Economic Research Service. (2014, July 10). Food security. Retrieved from http://www.ers.usda.gov/topics/food-nutrition-assistance/food-securityin-the-us.aspx\#.U77pLpRdXQg

United States Department of Agriculture (2014, July 10). Designated food desert census tracts. Retrieved from https://apps.ams.usda.gov/fooddeserts/TractBreakdown.pdf

United States Department of Agriculture. (2015, Oct. 13). Cooperative Extension. Retrieved from

https://www.usda.gov/wps/portal/usda/usdahome?contentid=cooperative_research_extension_ser vices.xml

United States Department of Agriculture (2016). Urban Agriculture Tool Kit. Retrieved from https://www.usda.gov/documents/urban-agriculture-toolkit.pdf

University of California Davis. (2015). Social, Health, and Economic Impacts of Local Food. Retrieved from http://asi.ucdavis.edu/programs/sarep/publications/food-and-society/ualitreview- 
2013.pdf

Vollmer, D. (Ed.). (2011). Pathways to Urban Sustainability: Lessons from the Atlanta Metropolitan Region: Summary of a Workshop. Washington, DC: National Academies Press.

Weber, C. L., \& Matthews, H. S. (2008). Food-miles and the relative climate impacts of food choices in the United States. Environmental science \& technology, 42(10), 3508-3513.

https://doi.org/10.1021/es702969f

Webber, C. B., \& Dollahite, J. S. (2008). Attitudes and behaviors of low-income food heads of households toward sustainable food systems concepts. Journal of Hunger \& Environmental Nutrition, 3(2-3), 186-205. https://doi.org/10.1080/19320240802243266

Wheater, H., \& Evans, E. (2009). Land use, water management and future flood risk. Land Use Policy, 26, S251-S264. https://doi.org/10.1016/j.landusepol.2009.08.019

Wheeler, S. M., \& Beatley, T. (2014). Sustainable Urban Development Reader. Routledge.

Whittinghill, L. J., \& Rowe, D. B. (2012). The role of green roof technology in urban agriculture. Renewable Agriculture and Food Systems, 27(04), 314-322.

https://doi.org/10.1017/S174217051100038X

Wittmer, I. K., Bader, H. P., Scheidegger, R., Singer, H., Lück, A., Hanke, I., ... \& Stamm, C. (2010). Significance of urban and agricultural land use for biocide and pesticide dynamics in surface waters. Water Research, 44(9), 2850-2862. https://doi.org/10.1016/j.watres.2010.01.030

\section{Author Information}

Sabine O'Hara is the Dean of the College of Agriculture, Urban Sustainability, and Environmental Sciences (CAUSES), and Director of Land-grant Programs of the University of the District of Columbia. A former provost, college president, and international education executive, she is well known for her work in community-based economic development and ecological economics.

Sabine O'Hara

College of Agriculture, Urban Sustainability, and Environmental Sciences (CAUSES)

University of the District of Columbia

4200 Connecticut Ave. NW

Washington D.C. 20008

E-mail: sabine.ohara@udc.edu

Telephone: 202-274-7011 